\title{
An Assessment of Potential Benefits to Smallholders of REDD+ Components in the Philippines
}

\author{
Rodel Lasco ${ }^{1}$, Florencia Pulhin ${ }^{2}$, Leonida Bugayong ${ }^{2}$ \\ and Marlo Mendoza ${ }^{3}$ \\ ${ }^{1}$ World Agroforestry Centre (ICRAF), Khush Hall, IRRI Campus, Los Banos, the \\ Philippines \\ ${ }^{2}$ Forestry Development Centre (FDC), College of Forestry and Natural Resources \\ (CFNR), University of the Philippines at Los Banos (UPLB), Los Banos, the \\ Philippines \\ ${ }^{3}$ Social Forestry and Forest Governance (SFFG) Department, University of the \\ Philippines at Los Banos (UPLB), Los Banos, the Philippines
}

\begin{abstract}
Many sectors in the Philippines are looking at the potential of Reducing Emissions from Deforestation and Forest Degradation-plus (REDD+) under the UN Framework Convention on Climate Change (UNFCCC) to help finance forest protection and rehabilitation in the country. However, one major problem is that there is little information on the potential benefits the country can expect under REDD+. Specifically, it is not known how each component activities of REDD+ can benefit smallholder farmers. Thus, this paper assesses the potential benefits of activities under REDD+ to smallholder farmers in the country. The key question is what the potential of REDD+ in the Philippines is for improving the sequestration potential of the forest sector and to serve as a form of supplemental livelihood for rural forest dwellers? The main approach of the paper is to summarize what is known about: the historical pattern of deforestation and degradation, the driving forces behind them, communitybased forest management (CBFM), tenure and rights, and to analyze the implications of Copenhagen and Cancun meetings for the Philippines. The main finding of the study is that depending on which REDD+ activity is implemented, smallholder farmers under CBFM areas would have varying roles and potential benefits. Smallholder farmers will benefit the most from avoiding forest degradation and enhancing of forest stocks activities because these activities pose the highest potential carbon credits. Due to the rising total forest cover of the country, very few carbon credits are expected from avoiding deforestation. This implies that government policies and programs could focus on preparing local communities and institutions for activities that decrease forest degradation and enhance carbon stocks. In addition, there are many uncertainties and information gaps remaining. For example, the rate of biomass degradation in Philippines forests and the drivers of forest degradation are still unknown. The ability of government agencies to implement REDD+ is still inadequate. A strong capacity building program is therefore essential.
\end{abstract}


Keywords: climate change mitigation, REDD, forest conservation, climate policy

\section{INTRODUCTION}

The land use, land use change, and forestry (LULUCF) sector, largely through tropical deforestation, is estimated to account for $1.6 \mathrm{Gt} \mathrm{C} / \mathrm{yr}$ of anthropogenic emissions or around $17-20 \%$ of the total greenhouse gas emissions (Denman et al., 2007; Nabuurs et al., 2007). More recent calculations have lowered this to $1.2 \mathrm{Gt} / \mathrm{yr}$ or about $12 \%$ of global emissions (Van der Werf et al., 2009). Despite its substantial contribution to total emissions, there remains a lack of concrete strategy in addressing emissions from LULUCF, especially from developing countries. A practical solution is to compensate land managers for the opportunity costs of changing land uses from high carbon-emitting practices to lower emitting ones; that is payment to not clear forests for agriculture. This is the rationale behind the proposal to include under the post-Kyoto agreements, as a mitigation measure, activities that avoid deforestation under the so-called Reducing Emissions from Deforestation and Forest Degradationplus (REDD+) mechanisms.

The Philippines is one of the most vulnerable countries to climate change and therefore has a huge stake in the outcome of climate change negotiations. For the period 1948-2005, a total of 1128 tropical cyclones entered the Philippine area of responsibility (PAR) and 56\% of these tropical cyclones reached typhoon intensity. There is no significant trend in the number of tropical cyclones from 1948-2005 suggesting that the effects of global warming are not yet evident. There is year-to-year variability in the number especially during El Niño and La Niña years with fewer numbers of tropical cyclones recorded in El Niño years (1967-68, 1972-73, 1997-98). With an increase in global temperature, this could mean stronger and more intense tropical cyclones in the Philippines as projected by the IPCC (Parry et al., 2007).

There is growing interest in the Philippines in participating with the emerging carbon market such as the Clean Development Mechanism (CDM) (Villamor and Lasco, 2009). Several reforestation and agroforestry projects have been developed in the last few years, although none has been registered with the CDM Executive Board. This is due to a number of reasons. First, purely from a financial perspective, income from carbon credits is not sufficient to recover the cost of tree planting. Using standard DENR (Department of Environment and Natural Resources) costs, planting and maintenance costs amount to about US\$1000 per hectare in the first three years. In contrast, income from carbon credits is about US\$250 per ha for ten years (at $5 \mathrm{tC} / \mathrm{ha}$ per year and US\$ 5 per tC) (Lasco et al., 2009; Lasco et al., 2003). This implies that carbon credits are best used as a supplemental source of income for farmers and project developers. Second, the transaction costs of forestry CDM projects are enormous and can be as high as US\$200,000 (Neef and Henders, 2007). This could prove to be the most significant barrier to the success of any CDM project. Third, the Philippines has not submitted its official forest definition to the UNFCCC CDM Executive Board which is a pre-requisite prior to project approval. At present, the official definition of the DENR is a $10 \%$ minimum crown cover, which can effectively rule out most agroforestry farms since they fall under forested lands. In contrast, a $30 \%$ cover will allow the inclusion of most agroforestry farms as CDM sites. 
With the apparent lack of success of forestry projects under CDM (Thomas et al., 2010), many sectors and international agencies are now looking at REDD+ as a promising mechanism to access carbon markets and financial mechanisms to fund projects. There are a number of options within the scope of REDD+ that are still major issues under negotiations. Policy makers in tropical developing countries are grappling with how the proposed REDD+ components will benefit their counties. For national policy makers, it is relevant to note that specific REDD+ activities will affect the amount of net carbon benefits their respective countries could potentially receive.

There is currently a lack of understanding regarding the implications of each REDD+ component to smallholder farmers. The objective of this paper is to assess the potential benefits of the various REDD+ options to smallholders in the Philippines. The key question of the paper is what is the potential of carbon forestry in the Philippines for improving the sequestration potential of the forest sector and to serve as a form of supplemental livelihood for rural forest dwellers? To address this question our main approach is to summarize what is known about the historical pattern of deforestation and degradation, the driving forces behind them, and CBFM, tenure and rights, as well as to analyze the implications of the Copenhagen and Cancun meetings for the Philippines.

\section{DRIVERS OF LAND USE CHANGE AND CARBON LINK}

\section{Historical and Current Forest Cover}

At the turn of the last century, $70 \%$ of total land area (21 million ha) of the country was covered with forests (Garrity et al., 1993). At present, only about 30\% (7 million ha) of forests remain, about 1 million ha of which are old-growth forests (Figure 1). There are perhaps 8 million ha of degraded forestland areas. Average deforestation rate from 1969 to 1973 was 170,000 ha per year (Forestry Development Centre, 1987).

Philippine forests have extremely high floral and faunal diversity. They harbour 13,000 species of plants, which comprise 5\% of the world's total (Department of Environment and Natural Resources/United Nations Environmental Program, 1997). With continued deforestation, some species previously occurring in certain areas are now extinct. In fact, the Philippines is one of the biodiversity 'hot spots' of the world (McNeely et al., 1990). The main strategy in biodiversity conservation is through the implementation of the National Integrated Protected Area System (NIPAS) Law. At present, 18 terrestrial and marine reserves have been proclaimed as initial components of NIPAS. However, many of these areas are protected merely on paper as they continue to be threatened and remain unprotected in part because of lack of resources. 


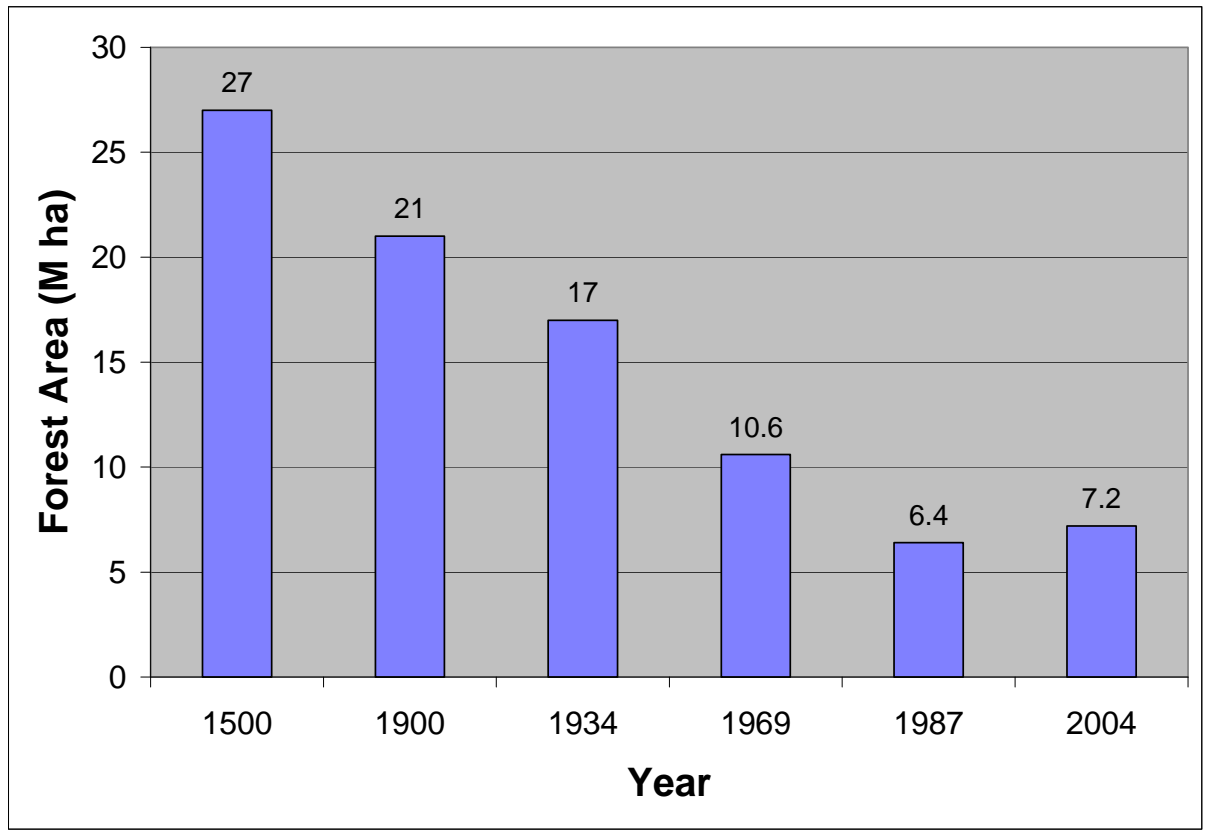

Source: Data from official statistics of the Forest Management Bureau (FMB, 2004, 2011) and Garrity et al. (1993)

Figure 1. Forest cover change in the Philippines

Since 1992, the Philippines has banned logging on all old-growth forests, mossy forests and those forests above 1000 meters above sea level, and with slopes greater than $50 \%$ which are primarily reserved for biodiversity and site conservation (Republic Act, 7586; Lasco et al., 2001). These forests are now part of a national integrated protected area system. It is estimated that there were 2.7 million ha of forest under protection in 1995 (FMB, 1996). These were mainly mossy forests (1.1 million ha) and old-growth Dipterocarp forests (0.8 million ha). With the enactment of the NIPAS law, there is now a stronger legal basis for the establishment and management of protected areas. However, the perennial lack of physical and human resources still pose as big problems in forest protection both in the short and medium term.

There was an estimated 2.8 million ha of second-growth forests in the Philippines in 1997 (FMB, 1998). The policy of the government since 1992 has been to rely on these forests as the main source of wood. Logging in natural forests is allowed only in second-growth Dipterocarp forests (Lasco et al., 2001). In 1997 there were 2.4 million ha of brushland areas in the Philippines. These are essentially remnants of tropical forests that were progressively degraded by excessive tree cutting. Currently, there is less than $20 \%$ forest cover (FMB, 2011). The main species comprising or contributing to forest cover are relic trees, shrubs and grasses. Given adequate protection, these areas are expected to regenerate and return to mature tropical forest. The main strategy of the government to rehabilitate the vast denuded areas is through reforestation and establishment of tree plantation (Chokkalingam et al. 2006), Typically, fast growing 
species such as Gmelina arborea, Acacia spp. and Eucalyptus spp. are used for plantation areas. Reforestation activities are supported by the government. Trees planted are intended primarily for providing permanent cover and are intended not to be cut. On the other hand, for tree farming, private enterprises establish tree plantations that are harvestable after about 10-15 years. In 1995, the rate of tree plantation establishment was estimated at 65,233 ha per year (FMB, 1996). However, the actual success rate is estimated at $42 \%$ (UNAC, 1992). There is no verifiable estimate of the total area currently planted. Official records show that 1.3 million ha were planted from 1976 to 1995.

Agroforestry involves the raising of woody perennials in conjunction with agricultural crops and/or livestock. The most common agroforestry systems in the Philippines are alley cropping and multi-storey systems (Agroforestry and Multipurpose Trees and Shrubs R\&D Team, 2003; Gascon et al., 2006). From the Forest Management Bureau's (FMB) official data (FMB, 2011), there are about 8 million ha of non-forested lands in the Philippine uplands and most of these could be cultivated in some form. This area includes both forest tree-based farms as well as coconut plantations (which are typically intercropped) and fruit orchards. However, a great portion of these areas are likely to be devoted to annual crops and are thus not true agroforestry systems. There is great uncertainty regarding the total area under upland farms since they are highly dynamic. Grassland areas can become upland farms and vice-versa. Except in patches of very small high-altitude areas, there are no natural grasslands in the Philippines. Hence, the estimated 2 million ha of grasslands (Moog, 2006) are anthropogenic and managed ecosystems. Previously forested, these grasslands are often the result of severe land degradation associated with deforestation and land tillage. If protected, they can be regenerated and restored to tropical forest conditions. However, these areas are regularly burned preventing plant succession from progressing naturally.

\section{Forest Cover Change and Its Drivers}

Over the last century, commercial logging was the main cause of the conversion of old-growth (primary) forests to secondary forests (Lasco et al., 2001). In addition, small-scale swidden farming was also responsible for the formation of secondary forests. Since 1900 the Philippines has lost about 15 million ha of tropical forests. Secondary forests could be converted to the following land uses: upland farms, pasture areas, brushlands and tree plantations. Conversion to upland farms is typically done by farmers who follow at the heels of loggers. Logged-over areas are easy to clear because the largest trees have been removed and logging roads provide easy access. Upland farms may revert to secondary forests when farmers choose to rest or fallow the land. Forest fallows are more often associated with indigenous farmers (Cairns, 2007). Several indigenous fallow systems have been documented in the Philippines (e.g. Gascon et al., 2006; Lasco, 2007). However, upland farms of farmers who migrated from the lowlands hardly, if ever, revert back to forests as they are continuously cultivated until the soils are degraded. Most grasslands in the Philippine uplands are formed in this manner (Dano, 1990; Snelder, 2001).

Clearing of secondary forests for pasture could also have happened in the past. However, it is more likely that pasture areas are former upland farms. When 
abandoned, pasture areas remain grasslands because of very poor soils. If fire is controlled, studies have shown that grasslands can return to a secondary forest through natural succession (Friday et al., 1999; Dugan et al., 2003). Secondary (logged-over) forests could become sub-marginal forests or brushlands as a result of continuous cutting of trees, mostly by illegal cutting. If further degraded, they could become grassland areas. However, if disturbance ceases, they revert to secondary forests.

In 1971 the area of residual forests (forests that resulted from logging activities) was almost the same as in 1997 (FMB, 1998). In contrast, the area of primary forest declined from more than 4.5 million ha in 1971 to less than 1.0 million ha in 1997 (FMB, 1998), a loss of 3.8 million ha in about 25 years. As explained previously, primary forests typically become secondary forests first before they are totally deforested. Since the area of secondary forests remained almost the same during the same period, it can be deduced that 3.8 million ha of secondary forests were also denuded in the same span of time or an average of about 140,000 ha per year of deforestation.

While the drivers of deforestation are clear, there is a lack of information on the drivers of biomass degradation in natural forests. This is a major gap considering that carbon credits from forest degradation comprise perhaps the major proportion of credits from forestry.

\section{Carbon Stocks of Land Cover Types}

In the last 15 years, there has been increasing research on the carbon stocks of Philippine forests and other land cover in public lands (also known as forestlands). A synthesis of the data available so far is shown in Table 1 . As shown in the table, old growth and secondary forests could contain more than $200 \mathrm{tC} /$ ha while a completely denuded area with grasses can contain approximately $12 \mathrm{tC} / \mathrm{ha}$ or about $5 \%$ as much carbon as a mature forest. This implies that $95 \%$ of above ground carbon could be lost due to deforestation. However, substantial amounts of carbon could also be lost due to forest degradation as can be seen in the lower carbon stocks of other cover types such as a tree plantation.

Lasco and Pulhin $(1998,2000,2001)$ previously estimated the total carbon stored in forestlands in the Philippines to be about 1100 TgC. In relative terms, total carbon stored in forestlands is equivalent to about 40 times the 1994 total net $\mathrm{C}$ emissions of the Philippines. Based on the methods in the 1996 IPCC Revised Methodology for Greenhouse Gas Inventory, the contribution of the LUCF sector in the Philippines has swung from being a net source in 1990 estimates to a strong net sink in 1998 estimates (Table 2). This change is due largely to newer activity data used in the recent estimates and the availability of new country-specific biomass data for the sector. The country became a net sink due to (a) lower rates of deforestation used in the most recent inventory and (b) the higher rate of carbon accumulation in forestlands. As forest areas shrink there are less and less forests left to clear. At the same time, the remaining forests are located in inaccessible areas thus the rate of deforestation has declined. There has been an increase in areas with degraded forests compared to earlier estimates which are assumed to be regenerating and accumulating carbon. 
Table 1. Mean above ground carbon density of forestland cover in the Philippines

\begin{tabular}{ll}
\hline Land cover & Carbon (tC/ha)
\end{tabular}
A. Protection forests
1. Old growth (from IPCC default values, Houghton et al., 1997)
$165-260$
2. Mossy
183.8
3. Pine
90.1
4. Mangrove
176.8
B. Secondary forest
207.9
C. Brushlands
29.0
D. Tree plantation
59.0
E. Agroforestry
45.4
F. Grasslands
12.1

Source: Lasco et al.( 2003).

Finally, it is worth noting that various Philippine forest types contain significant carbon stocks which could be released to the atmosphere if not protected. Historically, Lasco and Pulhin (1998) estimate that since the 1500s, the deforestation of 20.9 million ha of Philippine forests contributed $3.7 \mathrm{Pg}\left(10^{15} \mathrm{~g}\right.$ or billion tons) of carbon to the atmosphere of which 2.6 Pg tons were released in the last century.

Table 2. Total emissions from the LUCF sector of the Philippines ( $\mathrm{Gg} \mathrm{CO}_{2}$ equivalent)

\begin{tabular}{|c|c|c|c|c|}
\hline Source & $\begin{array}{c}1990 \\
\text { inventory } \\
\text { (1997 US } \\
\text { Country } \\
\text { Studies) } \\
\end{array}$ & $\begin{array}{c}1990 \\
\text { inventory } \\
(1998 \\
\text { ALGAS) }\end{array}$ & $\begin{array}{c}1994 \\
\text { inventory } \\
(1999 \\
\text { Philippine } \\
\text { Nat. Comm.) }\end{array}$ & $\begin{array}{c}1998 \\
\text { inventory } \\
\text { (Lasco and } \\
\text { Pulhin, } \\
\text { 2001) }\end{array}$ \\
\hline $\begin{array}{l}\text { Change in forests and } \\
\text { biomass stocks }\end{array}$ & $-48,654$ & 2622 & $-68,323$ & $-190,522$ \\
\hline $\begin{array}{l}\text { Forest and grassland } \\
\text { conversion }\end{array}$ & 120,738 & 80,069 & 68,197 & 46,624 \\
\hline $\begin{array}{l}\text { Abandonment of managed } \\
\text { lands }\end{array}$ & -1331 & -1331 & $\begin{array}{c}\text { Not } \\
\text { determined }\end{array}$ & $\begin{array}{c}\text { Not } \\
\text { determined }\end{array}$ \\
\hline Net emissions & 70,753 & 81,360 & -126 & - 142,007 \\
\hline Total Philippine emissions & 128,620 & 164,103 & 100,738 & 100,738 \\
\hline $\begin{array}{l}\% \text { of total Philippine } \\
\text { emissions }\end{array}$ & 55.01 & 49.58 & -0.13 & -142.00 \\
\hline
\end{tabular}

Source: Lasco et al., 2009 


\section{RIGHTS, RESOURCE ACCESS AND TENURE}

With carbon financing schemes available for forestland areas, property rights issues associated with these forest areas become important. Ownership issues including competition and rights to manage and control forestlands may intensify. Over the last two decades, community-based forest management (CBFM) has become an important flagship program of the government to address upland poverty and forestland management in the Philippines (Pulhin, 2004; Pulhin et al., 2006). To date, close to 6 million ha of forestlands are under some form of community forest management. Of these, about 4.7 million ha have been issued with different forms of land tenure instruments including around 1.62 million ha issued with Community Based Forest Management Agreement or CBFMA (FMB, 2007). CBFMA is an agreement entered into between the government and a local community, represented by a People's Organization, as forest managers. The agreement has a term of 25 years and is renewable for another 25 years. It allows communities that have formed local organizations to harvest timber from plantations and secondary forest subject to existing regulations on timber harvesting, on the condition that the area will be protected and managed according to the principles of sustained-yield forest management. The community must also use a portion of the income derived from harvesting to protect, renew and improve the forest resources, and to engage in alternative sources of livelihood.

There are 321,638 households that are involved in the implementation of the CBFM program (FMB, 2007). At an average size of about 6 persons per household in the Philippine uplands, this means that there are around 1.93 million people that are potential direct beneficiaries of the program.

Despite the impressive CBFM program coverage and potential beneficiaries, much needs to be done in order to fully achieve the stated CBFM objectives. These include among other things: capacity building of local communities and the other service institutions especially the DENR and the Local Government Units (LGUs), promoting sustainable livelihood of local communities, strengthening organizational linkages and support, solving the internal inconsistency of DENR's current organizational structure to effectively respond to the complex and multiple needs and demands of CBFM communities, simplification of CBFM procedures and requirements, and improving current management information and monitoring and evaluation system (Pulhin, 2005).

A key ingredient for the success of a REDD+ mechanism in the Philippine is the involvement of local communities now mainly organized under the CBFM. These communities live in the margins of the remaining forests and are their de facto managers and guardians.

Indigenous and forest-dependent communities are among those that stand to gain in the implementation of a REDD+ mechanism. Latest records show (Table 3) that there are a total of 140 approved and registered Certificates of Ancestral Domain Titles (CADTs) covering an area of about 3.6 million ha with 842,268 beneficiaries and 222 Certificates of Ancestral Land Titles (CALTs) over an area of 11,843 ha with 5939 right holders. Although 3.6 million ha of these ancestral domains and lands have been titled, there remain 111 CADTs and 159 CALTs approved but still going through 
the process of registration and titling over an aggregate area of 2.82 million ha and a total of 671,438 beneficiaries (NCIP, 2009).

The Indigenous People's Rights Act (IPRA) was enacted in 1997 through Republic Act No. 8371 in recognition of the rights and well-being of Indigenous Cultural Communities/Indigenous Peoples (ICC/IP) in the Philippines. Through this Law, the National Commission on Indigenous Peoples (NCIP) was created to formulate and implement policies, plans and programs for the recognition, promotion and protection of the rights and well-being of ICC/IP with due regard to their beliefs, customs, traditions and institutions. Among the functions of the NCIP is the formal recognition of ancestral domains and lands through the CADTs and CALTs. CADTs and CALTs are issued to ensure the IP's ownership of their ancestral domain and land.

Table 3. Number and area of approved CADTs and CALCs in the Philippines as of 30 October 2009

\begin{tabular}{|c|c|c|c|c|c|c|}
\hline Year & $\begin{array}{l}\text { No. of } \\
\text { ADs }\end{array}$ & Area (ha) & $\begin{array}{l}\text { No. of } \\
\text { right } \\
\text { holders }\end{array}$ & $\begin{array}{l}\text { No. of } \\
\text { ALs }\end{array}$ & Area (ha) & $\begin{array}{l}\text { No. of } \\
\text { right } \\
\text { holders }\end{array}$ \\
\hline 2002 & 2 & 41,256 & 18,283 & - & 0.00 & 0 \\
\hline 2003 & 9 & 326,020 & 58,389 & 44 & 42 & 178 \\
\hline 2004 & 18 & 236,436 & 73,421 & 4 & 919 & 251 \\
\hline 2005 & 9 & 233,810 & 36,743 & 2 & 2871 & 678 \\
\hline 2006 & 18 & 269,049 & 50,847 & 106 & 986 & 1579 \\
\hline 2007 & 2 & 94,426 & 22,585 & 13 & 12 & 4 \\
\hline 2008 & 38 & $1,241,543$ & 313,024 & 18 & 2611 & 1208 \\
\hline 2009 & 44 & $1,103,017$ & 268,976 & 35 & 4402 & 2041 \\
\hline Total & 140 & $3,545,557$ & 842,268 & 222 & 11,843 & 5939 \\
\hline $\begin{array}{l}\text { Total } \\
\text { Appro } \\
\text { and } C\end{array}$ & $\begin{array}{l}\text { of } \\
\text { CADTs } \\
s=\end{array}$ & 3,557,400.4135 & & $\begin{array}{l}\text { Total no } \\
\text { benefici } \\
\text { \& CALI }\end{array}$ & (CADT & 848,207 \\
\hline \multicolumn{7}{|c|}{ Approved CADTs and CALCs but in the process of Registration } \\
\hline Total & 111 & $2,816,280$ & 666,723 & 159 & 8587 & 4715 \\
\hline $\begin{array}{l}\text { Total } \\
\text { appro } \\
\text { and C } \\
\text { proces } \\
\text { registr }\end{array}$ & $\begin{array}{l}\text { of } \\
\text { CADTs } \\
\text { s on } \\
n=\end{array}$ & $2,824,867$ & & \multicolumn{2}{|c|}{$\begin{array}{l}\text { Total no. } \\
\text { beneficiaries (CADT } \\
\& C A L T) \text { on process } \\
\text { of registration = }\end{array}$} & 671,438 \\
\hline
\end{tabular}

Source: NCIP, 2009

Ancestral domains refer to 'all areas generally belonging to ICCs/IPs comprising lands, inland waters, coastal areas, and natural resources therein, held under a claim of ownership, occupied or possessed by ICCs/IPs, by themselves or through their ancestors, communally or individually since time immemorial to the present'. Ancestral lands are those lands 'occupied, possessed and utilized by individuals, families and clans who are members of the ICCs/IPs since time immemorial, by themselves or through their predecessors-in-interest, under claims of individual or 
traditional group ownership, continuously, to the present... for areas not limited to residential lots, rice terraces or paddies, private forests, swidden farms and tree lots'.

There is potential for ancestral domains and lands to qualify as REDD areas since many of these areas have substantial forest cover that can be managed under the REDD mechanism. Ancestral domains and lands also have the advantage of indigenous conservation and protection practices held by the ICCs/IPs. Studies and anecdotal references point to the Ikalahans of Nueva Vizcaya as one of the success stories in terms of managing their forests through both indigenous and scientific methods. They have even initiated A/R projects under the CDM market. Other ICCs/IPs that show promise include the Higaonons of Bukidnon who have preserved through centuries their cultural beliefs and practices closely associated with forests. Similarly, the Pala'wan tribe on the island of Palawan continue to adhere to their ageold cultural traditions in harmony with the forests (Phelps et al., 2009).

The ICCs/IPs mentioned above are potential operators of REDD projects because they have secure and legal land tenure of their ancestral domains and can be engaged as groups owing to their levels of leadership and organization as well as a legal status that allows them to enter into contracts with other parties for the management of forests within their domain. Such advantages could ensure meaningful community participation, equitable benefit sharing, as well as social safeguards in REDD negotiations (Phelps et al., 2009).

\section{POTENTIAL BENEFITS OF REDD+COMPONENTS}

More recently, several government and non-government organizations nationally and internationally have been advocating financial mechanisms such as payments for avoided deforestation in developing countries under the so-called 'Reducing emissions from deforestation and degradation-plus' (REDD+), perhaps in the post-2012 agreement. This is in part because it has long been recognized that deforestation, mainly in the tropics, account for about $12 \%$ of all anthropogenic greenhouse gas emissions (Van der Werf et al., 2009). However, it has also been recognized that 'the design and implementation of REDD policies will be neither simple nor straightforward, given the complexity of the social, economic, environmental and political dimensions of deforestation. Many of the underlying causes of deforestation are generated outside the forestry sector, and alternative land uses tend to be more profitable than conserving forests' (Kanninen et al., 2007 p. vii).

In the Copenhagen meeting of the parties to the UNFCCC, the REDD+ negotiations were one of the highlights (La Vina, 2010). The resulting Copenhagen Accord (2009) recognized the crucial role of reducing emission from deforestation and forest degradation. The parties of the Accord agreed to the immediate establishment of a REDD-plus mechanism. There is also consensus among REDD+ negotiators to include the following components under REDD+: reducing emissions from deforestation; reducing emissions from forest degradation; conservation of forest carbon stocks; sustainable management of forest; and enhancement of forest carbon stocks (La Vina, 2010). Since then, there have been further advances in the negotiations as well as in implementing REDD+ activities in various countries. More than 40 developing countries are participants in the World Bank's Forest Carbon 
Partnership Facility. Eighteen of these countries have submitted Readiness Preparation Proposals (R-PP) to the Facility. While these plans include some indication on how they will implement REDD+, they are not necessarily linked to quantitative reduction targets (REDD-Net, 2010). At the Cancun meeting of parties in December 2010, the major building blocks of REDD+ were mostly in place. The Cancun Agreements officially launched the REDD+ mechanism under the UNFCCC (La Vina et al., 2011).

In the following section the likely benefits of each of the components under REDD+ to the participants of community based forest management (CBFM) in the Philippines are analyzed. Communities hosting CBFM projects stand to gain some benefits under REDD+ but the level will vary depending on the REDD+ component implemented (Table 4). CBFM sites contain forested areas or are near-forested lands. As such, local communities within CBFM sites can play a vital role in forest conservation. As shown in Figure 1, data from the DENR indicate that the rate of deforestation has tapered off and that forest cover in the Philippines is increasing. If this is the case, then the country and CBFM participants cannot expect payments for reducing deforestation since the baseline will show that deforestation is already declining without carbon payments. In other words, since national forest cover has been increasing recently, it can be argued that carbon finance is not needed to slow down deforestation.

However, a case may be made that, while total forest area is increasing, forest degradation is still taking place within the 7 million ha natural forests. Cutting of trees inside the forest through various forms of logging could lead to lower biomass and carbon stocks. For example in Mindanao, logging led to a decline of aboveground carbon stocks of about 50\% (100 Mg C ha-1) (Lasco et al., 2006). Under the avoided forest degradation component, CBFM communities could potentially benefit considering their major role in reducing biomass lost from forests. Some communities gather wood from forests for their own use such as for timber and fuelwood. The communities can also serve as guardians of the forest to prevent outsiders from illegally cutting trees and thus help lessen carbon loss.

CBFM communities will have greater potential to earn carbon payments through activities such as assisted natural regeneration and agroforestry. The whole 16 million ha of public lands in the uplands where CBFM communities are based will be included. It could also potentially mean that the afforestation and reforestation (A/R) components of the CDM can be combined with REDD+. From an ecological and practical standpoint, subsuming the current $A / R$ projects under the umbrella of REDD+ is ideal. Ecologically, forests areas can be treated holistically and there will be artificial boundaries between activities to reforest barren lands and protect existing forests within a landscape. This will be also make implementation easier and more integrated and could lower transaction costs (only one project instead of two). 
Table 4. Potential benefits for CBFM smallholders under various REDD+ components under discussion in the UN Framework Convention on Climate Change (UNFCCC)

\begin{tabular}{|c|c|c|c|c|}
\hline $\begin{array}{l}\text { REDD+ } \\
\text { Component }\end{array}$ & $\begin{array}{l}\text { Types of activities } \\
\text { included }\end{array}$ & $\begin{array}{c}\text { Land } \\
\text { included }\end{array}$ & $\begin{array}{l}\text { Role and benefits of } \\
\text { CBFM smallholders }\end{array}$ & $\begin{array}{l}\text { Policies and } \\
\text { institutions }\end{array}$ \\
\hline $\begin{array}{l}\text { Reducing } \\
\text { deforestation }\end{array}$ & $\begin{array}{l}\text { NONE- } \\
\text { Philippines forest } \\
\text { area increasing } \\
\text { recently so credit } \\
\text { is unlikely. }\end{array}$ & $\begin{array}{l}\text { Possibly } \\
\text { none }\end{array}$ & $\begin{array}{l}\text { None, since no land will } \\
\text { qualify. }\end{array}$ & $\begin{array}{l}\text { Department of } \\
\text { Environment and } \\
\text { Natural Resources } \\
\text { (DENR) will be the } \\
\text { lead unit involved } \\
\text { Key relevant policies: } \\
\text { Logging banned in all } \\
\text { natural forests } \\
\text { (Executive Order 23, } \\
\text { 2011) } \\
\text { Protected areas law } \\
\text { (Republic Act 7586, } \\
\text { 1992) } \\
\text { Law for indigenous } \\
\text { peoples' lands } \\
\text { (Republic Act 8371, } \\
\text { 1997) }\end{array}$ \\
\hline $\begin{array}{l}\text { Reducing } \\
\text { deforestation } \\
\text { + Reducing } \\
\text { degradation }\end{array}$ & $\begin{array}{l}\text { In the Philippines, } \\
\text { there is anecdotal } \\
\text { evidence that } \\
\text { forest degradation } \\
\text { (e.g. illegal } \\
\text { cutting) is } \\
\text { occurring. }\end{array}$ & $7 \mathrm{M}$ ha & $\begin{array}{l}\text { CBFM smallholders are } \\
\text { potential beneficiaries as } \\
\text { 'guardians' of the forest. } \\
\text { They can help protect forests } \\
\text { from loss of biomass } \\
\text { through logging and } \\
\text { fuelwood gathering, and } \\
\text { also assist local authorities } \\
\text { in preventing encroachment } \\
\text { of migrants in natural } \\
\text { forests. In this role, } \\
\text { smallholders could have a } \\
\text { share of carbon payments. }\end{array}$ & $\begin{array}{l}\text { DENR will be the lead } \\
\text { unit involved } \\
\text { Policies as above and in } \\
\text { addition: } \\
\text { CBFM as national } \\
\text { strategy for sustainable } \\
\text { forestry (Executive } \\
\text { Order 263, 1995) }\end{array}$ \\
\hline $\begin{array}{l}\text { Reducing } \\
\text { deforestation } \\
\text { + Reducing } \\
\text { degradation + } \\
\text { Enhancing } \\
\text { carbon stocks } \\
\text { in the forest }\end{array}$ & $\begin{array}{l}\text { Reducing the rate of } \\
\text { biomass degradation } \\
\text { in forests } \\
\text { Enrichment planting } \\
\text { Assisted natural } \\
\text { regeneration (ANR) } \\
\text { Reforestation/ } \\
\text { agroforestry }\end{array}$ & $\begin{array}{l}7 \mathrm{M} \text { ha of } \\
\text { forests } \\
9 \mathrm{M} \text { ha of } \\
\text { open lands } \\
\text { in 'forest' } \\
\text { lands }\end{array}$ & $\begin{array}{l}\text { Same as above. } \\
\text { In addition, CBFM } \\
\text { smallholders can implement } \\
\text { projects that enhance carbon } \\
\text { sequestration such as } \\
\text { agroforestry, reforestation, } \\
\text { and ANR in open lands } \\
\text { under their management. } \\
\text { These will increase carbon } \\
\text { payments for smallholders. }\end{array}$ & $\begin{array}{l}\text { DENR will be the lead } \\
\text { unit involved } \\
\text { Department of } \\
\text { Agriculture (DA) could } \\
\text { also be involved } \\
\text { Policies same as above }\end{array}$ \\
\hline
\end{tabular}


In light of the foregoing discussion, a national REDD+ strategy should include the following:

1. Research into the dynamics of biomass degradation and aggradation in existing forests and its implications for carbon stocks. Since the country is pinning its hopes on the second $\mathrm{D}$, this is crucial.

2. Research into the direct and indirect drivers of degradation and aggradation in natural forests. This will shed light on which levers are critical in minimizing degradation.

3. Reference baselines need to be clear so that carbon stocks and REDD-related activities can be properly measured/monitored, reported, and verified.

4. A governance structure for REDD+ including an equitable and realistic way of sharing carbon payments to local communities including indigenous peoples.

5. A robust capacity building program on REDD+ implementation for the DENR, LGUs and civil society partners.

6. Economic analysis of the various modes of carbon payments. Are they costeffective ways of combating forest degradation?

These issues and concerns have been discussed in the many consultations recently done for the drafting of the Philippine National REDD-plus Strategy (PNRPS). It is hoped that these will be properly addressed once the PNRPS is adopted by the country as part of the National Framework Strategy on Climate Change (NFSCC) under the Climate Change Act (Republic Act No. 9729). The NFSCC has incorporated REDD+ as a key result area in its Mitigation Pillar. Likewise, Executive Order (EO) No. 881 dated 26 April 2010, includes REDD+ programs, action plans and related mechanisms within the scope of coordination by the Climate Change Commission. It also mandates the DENR as the operational implementer of REDD+.

At the time of writing, the PNRPS had been endorsed by the DENR to the Climate Change Commission on 27 August 2010 for official adoption by the Commission. The PNRPS was drafted by a pool of writers from various civil society groups, the academe, research institutions, local government, and the DENR including its bureau representatives (Forest Management Bureau, Ecosystems Research and Development Bureau, Parks and Wildlife Bureau, NCIP, NAMRIA, etc.).The Philippine National REDD+ Strategy action plan and budget has been drafted and is currently being finalized.

\section{GAPS AND RESEARCH NEEDS}

In the last ten years, greater information has been generated from research studies on the carbon stocks and sequestration of Philippine forests as described above. With existing data, it is relatively easier to estimate the potential carbon credits from loss of forests or deforestation than forest degradation. However, since the Philippines does not stand to gain credit from reducing deforestation this will be of little value for carbon credits. There is very little information on forest degradation rates in Philippine forests. As mentioned earlier, one study showed that logging activities could deplete 
up to $50 \%$ of carbon (Lasco et al., 2000). However, the forest biomass recovers with time to perhaps almost the same as before logging. Another possible indicator of degradation is fuelwood gathering. Per capita estimates exist but it is not certain whether the wood comes from natural forest or from scattered trees on private lands. Thus, to be able to assess potential REDD+ benefits for the Philippines there is a need to study the rate of forest degradation in various ecosystem types and geographic locations. One way to do this is to check forest inventory records, which may provide some idea of the order of magnitude of forest degradation. Remote sensing techniques coupled with Geographic Information System (GIS) analysis should be explored. The role of the National Mapping and Resource Information Authority (NAMRIA) could be crucial.

A second information gap relates to drivers of forest degradation in Philippine forests. These are crucial in designing policies and measures to reduce degradation. The most common culprits are well known - illegal cutting, timber poaching, fuelwood gathering. However, empirical data are lacking. Another issue that needs to be addressed is the need for the testing of available or developing technologies for measuring/monitoring, reporting and verifying carbon stocks and determining reference baselines. Should carbon payments start flowing to the country as a result of REDD+ financing, how the funds will be shared to local communities including indigenous people has not yet been investigated. The capacity of the DENR as well as other local government units to implement and monitor REDD+ at the national and local level is still weak. A capacity building program may need to be undertaken perhaps by experts from the UNFCCC and other international organizations to capacitate the various agencies of government and its civil society partners.

\section{CONCLUSIONS}

Philippine forests have been badly depleted during the last century. More recently, they are showing signs of recovery as forest areas begin to expand. However, there are fears that loss of biomass may be continuing unabated within forests. REDD+ provides a potentially significant source of external financing to help arrest biomass loss that contributes to greenhouse gas emissions. CBFM communities stand to gain at varying levels, contingent on which REDD+ component is implemented within the country.

This study has shown that there is currently little possibility of obtaining carbon credits for avoiding deforestation from the national perspective because the forest cover has been increasing in the last decade. The potential for credits through avoiding forest degradation exists but the level is not yet known and more research is needed. The potential for activities that enhance carbon stocks is clear. However, the lack of a forest carbon market and the lack of clear policy guidelines for REDD+ at international and national levels could stifle interest in REDD+ activities.

There are still wide-ranging issues that need to be addressed for this to be a reality. There is little information on the extent of biomass degradation in Philippine forests, if any. This should be a first priority for future research. The role of CBFM communities is vital but exactly how they will participate is not clear. How carbon payments will filter down to CBFM members is also uncertain. 
Institutionally, the DENR in general (as designated operational implementer for REDD + ) and the Forest Management Bureau (FMB) in particular, lack the capacity to implement REDD+ activities. Although a number of the FMB's staff are involved in the PNRPS discussions and drafting, there are very few staff at FMB and at the field level who keep abreast of developments in REDD+. Civil society groups are in fact driving the REDD+ discourse in the country. Thus, capacity building for government personnel is absolutely essential.

\section{ACKNOWLEDGMENTS}

The authors would like to acknowledge the support provided by the GTZ Philippines through its ACCBio project with the DENR and the Alternatives to Slash and Burn (ASB) program and the RUPES project of ICRAF in the preparation of this paper. We are grateful to two anonymous reviewers whose comments highly improved the paper. However, the authors bear responsibility for the contents of the paper.

\section{REFERENCES}

AGROFORESTRY AND MULTIPURPOSE TREES AND SHRUBS R\&D TEAM. 2003. $R \& D$ Status and Directions (2000 and beyond): Agroforestry and multipurpose trees and shrubs. PCARRD, Los Baños, Laguna. 45 pp.

CAIRNS, M. (ed.). 2007. Voices from the Forest: Integrating Indigenous Knowledge into Sustainable Upland Farming. Resources for the Future: Washington, DC. 826 pp.

CHOKKALINGAM, U., CARANDANG A.P., PULHIN J.M., LASCO R.D., PERAS R.J.J. and T. TOMA. 2006. One century of forest rehabilitation in the Philippines: approaches, outcomes and lessons. Bogor, Indonesia: Centre for International Forestry Research (CIFOR). $132 \mathrm{pp}$.

DANO, A. 1990. Effect of burning and reforestation on grassland watersheds in the Philippines. In: Research Needs and Applications to Reduce Erosion and Sedimentation in Tropical Steeplands, Proceedings of the Fiji Symposium, June 1990. IAHS-AISH Publ. No.192, 1990. pp. 53-61.

DENMAN, K.L., BRASSEUR, G., CHIDTHAISONG, A., CIAIS, P., COX, P.M, DICKINSON, R.E., HAUGLUSTAINE, D., HEINZE, C., HOLLAND, E., JACOB, D., LOHMANN, U., RAMACHANDRAN, S., DA SILVA DIAS, P.L., WOFSY, S.C. and X. ZHANG. 2007. Couplings between changes in the climate system and biogeochemistry. In: S. Solomon, D. Qin, M. Manning, Z. Chen, M. Marquis, K.B., TIGNOR, A.M. and H.L. Miller (eds.), Climate Change 2007: The Physical Science Basis. Contribution of Working Group I to the Fourth Assessment Report of the Intergovernmental Panel on Climate Change. Cambridge University Press, Cambridge, U.K. and New York, NY, USA.

DENR/UNEP (DEPARTMENT OF ENVIRONMENT AND NATURAL RESOURCES/UNITED NATIONS ENVIRONMENT PROGRAM). 1997. Philippine Biodiversity: An Assessment and Action Plan. Bookmark Inc., Manila, Philippines.

DUGAN, P.C., DURST, P.B., GANZ, D.J. and P.J. MCKENZIE. 2003. Advancing Assisted Natural Regeneration (ANR) in Asia and the Pacific. RAP PUBLICATION 2003/19. FAO, Bangkok. 44 pp. 
EXECUTIVE ORDER NO. 881. 2010. Authorizing the Climate Change Commission to coordinate existing climate change initiatives, reducing emissions from deforestation and forest degradation-plus, and other similar mechanisms. Malacanang, 26 April 2010.

FMB (FOREST MANAGEMENT BUREAU). 1998. Philippine Forestry Statistics. Forest Management Bureau. DENR, Quezon City Philippines.

FMB. 2004. Philippine Forestry Statistics. Forest Management Bureau. DENR, Quezon City, the Philippines.

FMB. 2011. Philippine Forestry Statistics. DENR, Quezon City, Philippines. http://forestry.denr.gov.ph/stat2008.htm. Accessed 22 February 2011.

FRIDAY, K., DRILLING, M.E. and D.P. GARRITY. 1999. Imperata Grassland Rehabilitation Using Agroforestry and Assisted Natural Regeneration. International Centre for Research in Agroforestry, Bogor, Indonesia.

GARRITY, D.P., D.M. KUMMER and E.S. GUIANG. 1993. The upland ecosystem in the Philippines: alternatives for sustainable farming and forestry. National Academy Press, Washington DC.

GASCON, C.N., GASCON, F. and K. TAKAHASHI (eds). 2006. Agroforestry systems in the Philippines: experiences and lessons learned in Mt. Banahaw, Hanunuo Mangyan and some community-based forestry projects. Japan International Research Centre for Agricultural Sciences, Southern Luzon Polytechnic College, and University of the Philippines Los Baños, the Philippines. 119 pp.

IPCC (INTERGOVERNMENTAL PANEL ON CLIMATE CHANGE). 2000. The carbon cycle and atmospheric carbon dioxide. In: Land Use, Land-Use Change and Forestry: A Special Report of the International Panel on Climate Change, R.T. Watson, I.R. Noble, B. Bolin, N.H. Ravindranath, D. Verardo, D. Dokken (eds). Cambridge University Press, Cambridge.

IPCC 2001. Climate Change 2001: Impacts, Adaptation and Vulnerability. Summary for Policy Makers and Technical Summary of the Working Group II Report. World Meteorological Organization (WMO), Geneva, Switzerland and UN Environmental Programme (UNEP), Nairobi, Kenya. 89 pp.

KANNINEN, M., MURDIYARSO, D., SEYMOUR, F., ANGELSEN, A., WUNDER, S. and L. GERMAN. 2007. 'Do Trees Grow on Money? The Implications of Deforestation Research for Policies to Promote REDD’. Bogor, Indonesia: Centre for International Forestry Research (CIFOR).

KUMMER, D.M. 1990. Deforestation in the Post-war Philippines. PhD dissertation, Boston University, Boston, MA.

LASCO, R.D. and F.P. PULHIN. 1998. Philippine Forestry and CO2 Sequestration: Opportunities for Mitigating Climate Change. Environmental Forestry Programme (ENFOR), CFNR, UPLB, College, Laguna, Philippines. 24 pp.

LASCO, R.D. and F.B. PULHIN. 2000. Forestland use change in the Philippines and climate change mitigation. Mitigation and Adaptation to Global Change. 5: 81-97.

LASCO, R.D. and F.B. PULHIN. 2001. Forestry mitigation options in the Philippines: application of the COMAP model. Mitigation and Adaptation Strategies to Global Change. 6: 313-334.

LASCO, R.D. and F.B. PULHIN. 2003. Philippine forest ecosystems and climate change: Carbon stocks, rate of sequestration and the Kyoto Protocol. Annals of Tropical Research. 25(2), 37-51. 
LASCO, R.D. 2007. The Naalad improved fallow system in the Philippines and its implications for global warming. In: Voices from the Forest: Integrating Indigenous Knowledge into Sustainable Upland Farming. M. Cairns (ed.). Resources for the Future: Washington, DC. pp. 301-305.

LASCO, R.D. and PULHIN, F.B. 2009. Carbon budgets of forest ecosystems in the Philippines. Journal of Environmental Science and Management. 12(1): 1-13.

LASCO, R.D., VISCO, R.G. and J.M. PULHIN. 2001. Secondary forests in the Philippines: formation and transformation in the 20th century. Journal of Tropical Forest Science. 13(4): 652-670.

LASCO, R.D., MACDICKEN, K., PULHIN, F.B., GUILLERMO, I.Q., SALES, R.F. and R.V.O. CRUZ. 2006. Carbon stocks assessment of a selectively logged dipterocarp forest and wood processing mill in the Philippines. Journal of Tropical Forest Science. 18(4): 212-221.

LA VIÑA, A.G.M. 2010. The Future of REDD-Plus: Pathways of Convergence for the UNFCCC Negotiations and the Partnership. FIELD Working Paper. Document available at www.feld.org.uk. Accessed 20 September 2010.

LA VINA, A.G.M., LAWRENCE, A.N.G. and J. DULCE. 2011. The Cancun Agreements: Do they advance global cooperation on climate change? Working Paper, London: Foundation for International Environmental Law and Development. www.field.org.uk/files/lavinaang_from_copenhagen_to_cancun.pdf. Accessed 25 February 2011.

MCNEELY, J.A., MILLER, K.R., REED, W.V., MITTERNMEIER, R.A. and T.B. WERNER. 1990. Conserving the World's Biological Diversity. IUCN, Gland, Switzerland; WRI, CI, WWF-US and the World Bank, Washington DC.

MOOG, F. 2006. Country Pasture/Forage Resource Profiles: Philippines. Food and Agriculture Organization (FAO), Rome. http://www.fao.org/ag/AGP/AGPC/doc/ counprof/Philippines/Philipp.htm. Accessed 25 February 2011.

NABUURS, G.J., MASERA, O., ANDRASKO, K., BENITEZ-PONCE, P., BOER, R., DUTSCHKE, M., ELSIDDIG, E., FORD-ROBERTSON, J., FRUMHOFF, P., KARJALAINEN, T., KRANKINA, O., KURZ, W.A., MATSUMOTO, M., OYHANTCABAL, W., RAVINDRANATH, N.H., SANZ SANCHEZ, M.J. and X. ZHANG. 2007. Forestry. In: B. Metz, O.R. Davidson, P.R. Bosch, R. Dave and L.A. Meyer (eds), Climate Change 2007: Mitigation. Contribution of Working Group III to the Fourth Assessment Report of the Intergovernmental Panel on Climate Change. Cambridge, Cambridge University Press, UK and New York, NY, USA. pp. 541-584.

NATIONAL COMMISSION ON INDIGENOUS PEOPLE. 2009. Summary data on approved CADCs and CALTs.

CLIMATE CHANGE COMMISSION. 2010. National Framework Strategy on Climate Change, 2010-2022. Malacanang, Manila.

NEEF, T. and S. HENDERS. 2007. Guidebook to Markets and Commercialization of Forestry CDM Projects. Turrialba, Costa Rica, Centro Agronomico Tropical de Investigacion (CATIE).

PARRY, M.L., CANZIANI, O.F., PALUTIKOF, J.P et al. 2007 Technical Summary. Climate Change 2007: Impacts, Adaptation and Vulnerability. Contribution of Working Group II to the Fourth Assessment Report of the Intergovernmental Panel on Climate Change, M.L. Parry, O.F. Canziani, J.P. Palutikof, P.J. van der Linden and C.E. Hanson (eds). Cambridge University Press, Cambridge, UK. pp. 23-78. 
PHELPS, J.M., GUERRERO, C., DALABAJAN, D.A., WEBB, E.L. and B. YOUNG. 2009. What makes a 'REDD' Country? Global Environmental Change. 20: 322 332.

PULHIN, J.M. 2005. Enhancing the Philippines' CBFM Implementation Strategy: A Synthesis Report Based on the Findings of Six Case Studies. A draft report of six in-depth case studies on CBFM with funding support from the National Forest Programme Facility through the Food and Agriculture Organization.

PULHIN, J.M. 2004. Devolution of Forest Management in the Philippines. A paper presented during the workshop on Evolution of Devolution: Contributing to Participatory Forestry in Asia-Pacific?, Bangkok, Thailand, 25-26 March 2004.

PULHIN, J.M., CHOKKALINGAM, U., PERAS, R.J.J., ACOSTA, R.T., CARANDANG, A.P., NATIVIDAD, M.Q., LASCO, R.D. and R.A. RAZAL. 2006. Chapter II Historical overview. In: U. Chokkalingam, A.P. Carandang, J.M. Pulhin, R.D. Lasco, R.J.J. Peras, and T. Toma (eds), Century of Forest Rehabilitation. The Philippines: Approaches, Outcomes and Lessons. Bogor, Indonesia: Centre for International Forestry Research (CIFOR). pp. 6-43.

REDD-NET. 2010. REDD+ targets: what is currently on the table? www.redd-net.org. Accessed 20 September 2010.

REPUBLIC ACT NO. 8371. 1997. The Indigenous Peoples’ Rights Act (IPRA) of 1997. Manila, Republic of the Philippines.

REPUBLIC ACT NO. 7586. 1992. An Act Providing for the Establishment and Management of National Integrated Protected Areas System, Defining its Scope and Coverage, and for other Purpose. Manila, Republic of the Philippines.

REVILLA, A.V. 1997. Working Paper for the Forestry Policy Agenda for the Incoming Administration, College of Forestry and Natural Resources, University of the Philippines at Los Banos, Laguna.

SNELDER, D.J. 2001. Soil properties of Imperata grasslands and prospects for tree-based farming systems in Northeast Luzon, the Philippines. Agroforestry Systems. 52: 2740.

THOMAS, S., DARGUSCH, P., HARRISON, S. and J. HERBOHN. 2010. Why are there so few afforestation and reforestation Clean Development Mechanism projects? Land Use Policy. 27(3): 880-887.

UNAC (UPLAND NGO ASSISTANCE COMMITTEE). 1992. An Assessment of Selected Contract Reforestation Projects: UNAC Survey. Fresan Printing Press, Quezon City, the Philippines.

VAN DER WERF, G.R., D.C. MORTON, R.S. DEFRIES, J.G.J. OLIVIER, P.S. KASIBHATLA, R.B. JACKSON, G.J. COLLATZ and J.T. RANDERSON. 2009. CO2 emissions from forest loss. Nature Geoscience 2: 737-738.

VILLAMOR, G.B. and R.D. LASCO. 2009. Rewarding upland people for forest conservation: experience and lessons learned from case studies in the Philippines. Journal of Sustainable Forestry. 28(3-5): $304-321$.

WATSON, R.T., NOBLE, I.R., BOLIN, B., RAVINDRANATH, N.H., VERADO, D.J. and D.J. DOKKEN (eds). 2000. Land Use, Land-use Change, and Forestry, Published for the Intergovernmental Panel for Climate Change, Cambridge University Press. 